\title{
Brazilian spotted fever in cart horses in a non-endemic area in Southern Brazil
}

\author{
Febre maculosa brasileira em cavalo de carroceiro em área não-endêmica no Sul do Brasil \\ Marta Cristina Diniz de Oliveira Freitas ${ }^{1}$; Marcelly Grycajuk ${ }^{1}$; Marcelo Beltrão Molento ${ }^{1 *}$; José Bonacin²; \\ Marcelo Bahia Labruna ${ }^{3}$; Richard de Campos Pacheco³; Jonas Moraes-Filho33; Ivan Deconto; \\ Alexander Welker Biondo ${ }^{1}$
}

\begin{abstract}
'Laboratório de Doenças Parasitárias, Departamento de Medicina Veterinária, Setor de Ciências Agrárias, Universidade Federal do Paraná - UFPR

${ }^{2}$ Secretaria Municipal de Saúde, Centro de Controle de Zoonoses - CCZ, Prefeitura de São José dos Pinhais

${ }^{3}$ Departamento de Medicina Veterinária Preventiva e Saúde Animal, Faculdade de Medicina Veterinária e Zootecnia, Universidade Federal do Paraná - UFPR
\end{abstract}

Received January 5, 2010

Accepted February 9, 2010

\begin{abstract}
Brazilian Spotted Fever (BSF) is an often fatal zoonosis caused by the obligate intracellular bacterium Rickettsia rickettsii. The disease is generally transmitted to humans by Amblyomma spp. ticks. Serological evidence of past infection by $R$. rickettsii has been reported in horses, but the pathogenicity of $R$. rickettsii in horses remains unknown. Cart horses are still widely used in urban and urban fringe areas in Brazil, and these animals may constitute suitable sentinels for BSF human in these areas, for example, in Sao Jose dos Pinhais, where the first BSF human case in the state of Parana was diagnosed. Serum samples were randomly obtained from 75 cart horses between April 2005 and June 2006 and were tested by means of the indirect immunofluorescence assay (IFA) for antibodies against rickettsia of the spotted fever group. A total of $9.33 \%$ of the animals were considered positive, with titers ranging from 64 to 1,024 . These results indicate the presence of the agent in such areas, although at low rates.
\end{abstract}

Keywords: Brazilian spotted fever, Rickettsia, serology, horses, epidemiology.

\section{Resumo}

A febre maculosa brasileira (FMB) é uma zoonose, muitas vezes fatal, causada pela bactéria intracelular obrigatória Rickettsia rickettsii. A doença é transmitida para humanos pelo carrapato Amblyomma spp. Sorologia positiva por $R$. rickettsii foi relatada em cavalos, entretanto a patogenia de $R$. rickettsii em cavalos é desconhecida. Cavalos de carroceiros ainda são largamente utilizados em áreas urbanas e peri-urbanas no Brasil e estes animais podem representar sentinelas ideais para FMB nestas áreas, como exemplo, São José dos Pinhais, onde o primeiro caso humano de FMB foi descrita no Paraná. Amostras de soro foram obtidas aleatoriamente de 75 cavalos de carroceiros entre abril de 2005 e junho de 2006 e testados pela reação de imunofluorescência indireta (RIFI) com anticorpos contra riquétsias do grupo da febre maculosa. Um total de 9,33\% dos animais foi considerado positivo, com títulos entre 64 e 1.024 . Estes resultados indicam a presença do agente na área de estudo, embora em nível reduzido.

Palavras-chave: Febre maculosa brasileira, Rickettsia, sorologia, cavalos, epidemiologia.

Brazilian spotted fever (BSF) is the most important rickettsiosis that has been described in Brazil. It is caused by the Gram-negative obligate intracellular coccobacillary bacterium Rickettsia rickettsii (HORTA et al., 2007). Transmission occurs through bites from infected ticks, which keep the Rickettsia in their salivary glands, midgut cells and ovaries (HARDEN, 1990). The tick

\footnotetext{
*Corresponding author: Marcelo Beltrão Molento

Laboratório de Doenças Parasitárias, Departamento de Medicina Veterinária,

Setor de Ciências Agrárias, Faculdade de Medicina Veterinária e Zootecnia,

Universidade Federal do Paraná - UFPR,

Rua dos Funcionários, 1540, Curitiba - PR, Brazil;

e-mail: molento@ufpr.br
}

Amblyomma cajennense is considered to be the main vector of the disease in Brazil, especially in its immature stages. Horses, capybaras (Hydrochoerus hydrochaeris) and tapirs (Tapirus terrestris) are considered to be primary hosts for all parasitic stages of $A$. cajennense. On the other hand, larvae and nymphs of $A$. cajennense have low host specificity and are very aggressive to humans and domestic dogs. Human cases of BSF are normally accidental, and horses are considered to be sentinels for BSF because of their exposure to the vector $A$. cajennense (LEMOS et al., 1996).

Currently, the gold standard laboratory diagnostic test for BSF is the indirect immunofluorescence assay (IFA) (GALVÃO et al., 2005). Some Rickettsia species share similar surface antigens, thus 
resulting in cross-reaction between closely related species, especially those belonging to the spotted fever group (SFG), including $R$. rickettsii and $R$. parkeri, which have both been reported in Brazil (SILVEIRA et al., 2007). The objective of the present study was to determine the presence of anti- $R$. rickettsii reactive antibodies in horses that are used for collecting recyclable materials.

The study was performed in São José dos Pinhais, State of

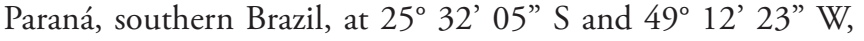
which has a population of 263,622 inhabitants, of which $90 \%$ are located in urban areas. Serum samples were obtained from 75 cart horses between April 2005 and June 2006. The animals were individually identified according to address, age, sex, clinical history and body condition scores. The ages of the animals (40 males and 35 females) ranged from 6 months to 22 years, with an average of 6.7 years of age. The distance traveled by the horses per day ranged from 8 to $40 \mathrm{~km}$.

Serum samples from the horses were individually tested by means of IFA, using crude antigens derived from $R$. rickettsii (strain Taiaçu) and $R$. parkeri (strain At24). The latter antigen was used only for serum samples collected in 2006. Antigen preparation and IFA reactions were performed as previously described (HORTA et al., 2007). Individual serum samples were initially screened at 1:64 dilution against each of the five rickettsial antigens. In the event of a positive reaction, serial two-fold serum dilutions were tested to determine endpoint titers.

The presence of anti-rickettsial antibodies (titer $\geq 64$ ) was detected in seven $(9.33 \%)$ out of the 75 horse sampled (Table 1 ), which were all positive for $R$. rickettsii with titers ranging from 64 to 1,024 . Horses 28, 32 and 38 were tested in 2005 for $R$. rickettsii alone, while all others were tested for both antigens. However, none of them was positive for $R$. parkeri.

Among the animals sampled, nine horses (11.84\%) were found to be parasitized by ticks at the time of blood collection. These ticks were subsequently identified as Amblyomma cajennense and Dermacentor nitens. Only one of the seropositive horses was found to be infested by ticks.

This study was conducted in the same area where the first human case of BSF in the State of Parana was diagnosed in 2005. In 1996, this disease became a compulsorily notifiable disease, and an epidemiological surveillance system was created in the State of São Paulo state after increasing numbers of cases started to be found among humans (LIMA et al., 2003). Since the differential diagnosis for this disease in relation to other exanthematic diseases such as leptospirosis, meningococcemia, Hantavirus and dengue is very difficult, it is suspected that underreporting of human cases occurs in Paraná because of diagnostic failure or noninclusion of differential diagnoses.

The data presented are in agreement with Cardoso et al. (2006), in which they found three positive horses (17\%) in
Table 1. Antibody titer in cart horses $(\mathrm{n}=75)$ using Rickettsia rickettsii and $R$. parkeri antigens.

\begin{tabular}{lccccc}
\hline Antibody titer & $\mathbf{1 : 6 4}$ & $\mathbf{1 : 1 2 8}$ & $\mathbf{1 : 5 1 2}$ & $\mathbf{1 : 1 , 0 2 4}$ & Total \\
\hline R. rickettsii & $2 / 75$ & $2 / 75$ & $2 / 75$ & $1 / 75$ & $7 / 75$ \\
$R$. parkeri & - & - & - & - & - \\
\hline
\end{tabular}

Caratinga, Minas Gerais. The authors took into consideration the risk of transmission of rickettsiosis in that region and the need to maintain continuous epidemiological surveillance for rickettsial diseases. In situations of high infestation by $A$. cajennense among horses, infestation in secondary hosts such as dogs and humans can occur (LEMOS, 1996; LABRUNA et al., 2002). The serological findings and the presence of the vector tick for BSF in Sao Jose dos Pinhais reinforce the need for a monitoring plan in the region. The risk of disease spreading exists because of the presence of seropositive horses.

\section{References}

CARDOSO, L. D. et al. Caracterização de Rickettsia spp: circulante em foco silencioso de febre maculosa brasileira no Município de Caratinga, Minas Gerais, Brasil. Cadernos Saúde Pública, v. 22, n. 3, p. 495-501, 2006.

GALVÃO, M. A. M. et al. Riquetsioses no Brasil e Portugal: ocorrência, distribuição e diagnóstico. Revista de Saúde Pública, v. 39, n. 5 , p. 850-856, 2005.

HARDEN, V. A. Rocky mountain spotted fever: history of a twentieth-century disease. Baltimore: Johns Hopkins University Press, 1990.324 p.

HORTA, M. C. et al. Rickettsia infection in five areas of the State of São Paulo, Brazil. Memórias do Instituto Oswaldo Cruz, v. 102, n. 7, p. 793-801, 2007.

LABRUNA, M. B. et al. Ticks (Acari: Ixodidae) on wild animals from the Porto-Primavera hydroelectric power station area, Brazil. Memórias do Instituto Oswaldo Cruz, v. 97, n. 8, p. 1133-1136, 2002.

LEMOS, E. R. et al. Infestation by ticks and detection of antibodies to spotted fever group Rickettsiae in wild animals captured in the State of São Paulo, Brazil. A preliminary report. Memórias do Instituto Oswaldo Cruz, v. 91, n. 6, p. 701-702, 1996.

LIMA, V. L. C. et al. Situação da febre maculosa na região administrativa de Campinas, São Paulo, Brasil. Caderno de Saúde Pública, v. 19, n. 1, p. 331-334, 2003.

SILVEIRA, I. et al. Rickettsia parkeri in Brazil. Emerging and Infectious Diseases, v. 13, n. 7, p. 1111-1113, 2007. 